\title{
sciendo
}

DOI: 10.2478/abcsj-2019-0001

American, British and Canadian Studies, Volume 32, June 2019

\section{A Man of Vision: Dumitru Ciocoi-Pop (1943-2019)}

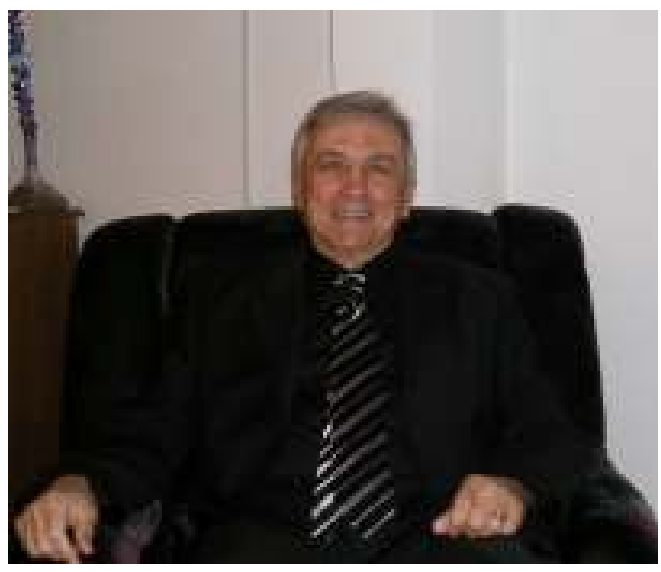

Dumitru Ciocoi-Pop, Rector of Lucian Blaga University of Sibiu between 1992 and 2004, was a man of many talents; above all, he was a scholar endowed with a deep and far-sighted vision. From the very moment he was elected Rector of the University of Sibiu, be realised that the time of parochialism had been over, that from then onwards isolation would grow grapes of wrath, and that just as no man is 'an island entire of itself,' no university with any real chance of survival in a bighly interconnected and interactive world, can grow and make a name for itself in isolation. He grasped an essential truth: international co-operation could turn the University of Sibiu into a gateway to world culture. Among the forty-eight state universities, eight military academies, and forty-nine private universities of post-Revolution Romania, this University had few chances by itself. Increased contacts with the world's academic communities might be its only chance.

Therefore, value and quality were to be the keywords of the new orientation of the University of Sibiu; quality and courage. The courage to start talking of your projects which seemed but figments of your wildest imagination. The courage to start building when most people were waiting for better times. 'De l'audace, encore de l'audace, toujours de l'audace.' But the Rector had always been a man of courage. A man who in times of lip-service did not hesitate to speak the truth, whatever the risk. A man whose will was not bent by the years of hardship and injustice. Those years, endless though 
they seemed, did notbing but strengthen his belief that darkness could not last forever; that a time would come when we would be free to pursue our ideals. Provided we managed to hang on to them. Provided we were left with any ideals after the dark years of totalitarianism. Provided we did not give in to the traumas and lingering influence of the former regime and its policy.

And then the time to accomplish his ideals finally came. The time for his dreams, which, in the words of one of his poems, 'were not a bridge of sighs across despair.'

He was elected Rector of the University of Sibiu in 1992. In time he realized that a four-year term was not long enough to see his dreams come true, to see his hopes accomplished. To bope is to deny the future. It is to force the future to conform to your way of thinking, to mould it as you wish. And he forced the future because he had his own future in mind. For the first time he spoke about a University which was to become a center of social renewal. When things were falling apart because 'the center could not hold,' he envisioned a University strongly anchored in the national and international academic community. He saw things for which, at that time, he did not even have a name. But he treasured them in his heart, waiting for their time to come. Because there is a time for everything. A time to destroy and a time to build. A time to dream and a time to see your dreams come true. A time to talk about your projects and a time to carry them out.

His first concern, after the 1992 elections, was to impart his vision to those close to him, to instil in them the conviction that it could be accomplished. Therefore he had to find the men who would enlist in the struggle, who would defy the scepticism of the 'wise', and would embrace his vision. He knew the wisdom of the gospel, that in order to accomplish a vision you need disciples. You need people to whom you should entrust your projects and who will embrace it. Even if one of them might betray you. But the other eleven will surely carry on the work.

Consequently, he gave a chance to all, irrespective of their past or present. Because that was the time for reconciliation, for putting the shoulder to the wheel, the time for unity and not for discord on account of past 
mistakes. Let the future judge all. Each according to his deeds. He thought his call was to encourage people. 'Take heart!', he would tell all those willing to take part in the shaping of the new University. 'Take heart! Nothing can exceed your powers, apart from fear. But I have overcome my fears. I have confronted them, I have looked them in the face, and they gradually vanished.'

He never despaired. Not even when he felt alone. Because in solitude you can better weigh the true value of your ideals. His ideals, which were sometimes dismissed as unrealistic by those close to him, were acknowledged as valid thousands of miles away. Because they had taken shape in the meantime. By 1996, things had changed in the Sibiu academe, and the University was becoming what it had been envisioned to be. The University of Missouri at Columbia, USA, acknowledged his merits by awarding him the Doctor Honoris Causa degree. He has distinguished himself among his peers in Romania and meets the highest academic and professional standards of excellence,' the laudatio read. 'He has demonstrated exceptional vision, courage and leadership in introducing and initiating many changes at the University of Sibiu, in a time when the University needed new ideas and courageous individuals who would risk advocating change.'

Rewards, however, did not lead to complacency. He knew he had to finish the work he had started, to continue carrying out the projects he had envisioned. He knew that finis coronat opus. He won his second and third terms as a Rector in a landslide, and continued the race in which be had engaged. A race against time, adversities of all sorts, and even against people.

A great talent spotter and pedagogue through and through, he always thought of others, of the young people who deserve equal study opportunities. After the dark years he had lived through, he understood that the best investment was in education, in forming and informing young people. 'Teach a child the way to wisdom, and when he is old he will not turn from it.' Therefore, if you want to change a nation, you must invest in education. You start by acting on the minds of people. You start with the minds of the people who have not been disheartened by the hardships of life. You start with the 
young who are easiest to shape. This is the reason why he wanted to give opportunities for study to all. He committed bimself to this task and would sacrifice the best in himself to see his vision accomplished. Another student, another life changed, and somewhere in the future, another contribution to the renewal of the country.

Therefore this obituary celebrates the scholar and the begetter of scholars that Dumitru Ciocoi-Pop was in his remarkable teaching career. While his lectures always had a mesmerizing effect on students, Dumitru CiocoiPop managed to inculcate in his students the conviction that literature is not a pastime but a vital enterprise, one that can change not only one's mind but one's life.

The range of his scholarly interests and his encyclopedic mind is evinced in the great variety of courses, undergraduate as well as graduate, he taught along the years. Thus, he taught a wide range of courses in the history of English and American literature with special emphasis on Modernism, as well as translation studies, twentieth-century Western culture and civilization, etc. He also supervised a large number of doctoral dissertations in fields ranging from Shakespearean drama through Postmodernism, from the Caribbean poet Derek Walcott to the African-American writer Alice Walker. While he was deeply respected for the wise guidance of his doctoral candidates' work, he was also feared for the high but unobtrusive standards he set for them.

Dumitru Ciocoi-Pop will also be remembered for the books be authored along the years. His most important contribution to the field of literary criticism remains his exegesis of Aldous Huxley's fiction entitled Aldous Huxley's Literary Ideology (1994). He was not only an insightful critic, but also a very refined translator, whose rendering of Lucian Blaga's poetry into English is one of the finest to date, his creative and recreative work rendering the poems a new and second voice worthy of their subtle nature. His remarkable translation of Blaga's poetry should be viewed from the perspective of his being himself a poet, whose two volumes of poems written in English - Doubting Certainties (1994) and Love Never Fails (1999) - point to his sensitivity as well as to his outstanding mastery 
of the English language. His translations of English prose (Aldous Huxley, Herman Melville) as well as his editing of A Bilingual Anthology of Romanian Poetry, together with the late Sever Trifu (1997) add to the image of a highly sophisticated intellectual.

Yet, the breadth of Dumitru Ciocoi-Pop's professional activities hardly gives a sense of the range of qualities of mind and character that his colleagues had the privilege to benefit from. To expatiate on his character and personality would be inappropriate in a commemorative piece; moreover, it would be distasteful to the man bimself. But a few things should not be left unsaid. Dumitru Ciocoi-Pop was a man of unaffected modesty, and behind the self-control exercised by the public persona one could perceive a man of great sensitivity and tenderness. His keenness of mind was evident in his wit as it was in his scholarship. Only a man endowed with remarkable powers of self-discipline could handle such a staggering range of activities, with a seriousness of mind that was exemplary. 'A few may comprehend that it is the strength to do one's duty daily and promptly that makes saints and heroes,' said Saul Bellow. Dumitru Ciocoi-Pop would not think of himself as either a saint or a hero. He would think of himself as an ordinary human being who cherished ideals worth fighting for, a man whose sense of responsibility to the others was uncompromising and unconditional. His extraordinary resources of will power helped him remain truthful to the conviction that the only possible means for attaining serenity and joy was submission to the imexorable natural laws with a total rejection of fear and self-interest.

As academic leader, teacher, scholar, poet and translator, and above all as a fascinating human being, Dumitru Ciocoi-Pop offered us the full measure of what a man can be. While living a life marked by severe ups and downs dictated by the unexpected turns of history, he found the strength 'to endure and prevail.' Or maybe, while apparently living in a buman body, be actually descended from the realm of legends to show us what a buman being can be and can become.

ALEXANDRA MITREA, 